\title{
تقييم الأداء الأكاديمي والتدريسي للطالبات المعلمات بقسم اللغة الإنجليزية بجامعة ACTFL نجران في ضوء معايير الكفاءة اللغوية
}

\author{
د. غيداء بنت علي صالح الزهراني

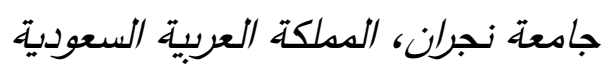 \\ كلية العلوم والآد/ب بثرورة
}

مستخلص. هدفت هذه الدراسة إلى تقييم الأداء الأكاديمي والتدريسي للطالبات المعلمات بقسم اللغة الإنجليزية بجامعة

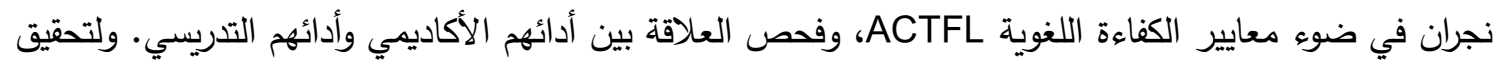

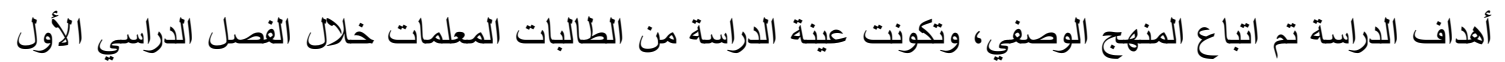

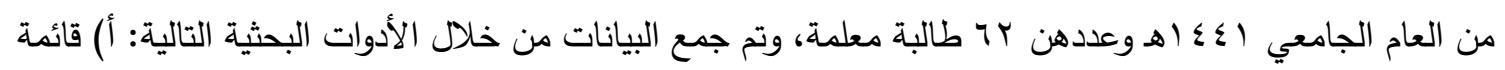

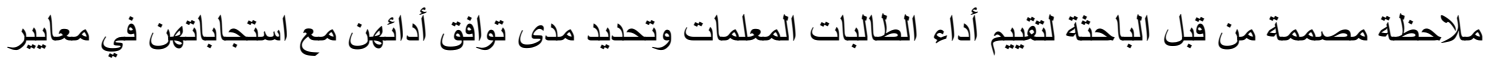
ACTFL

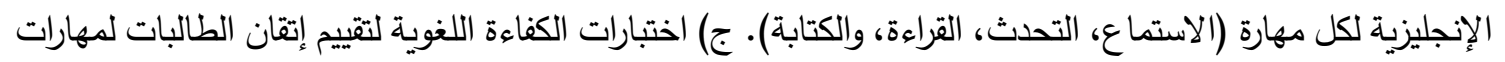
اللغة الإنجليزية الأربعة (الاستماع والتحدث والقراءة والكتابة) وربط هذه النتيجة باستجابات الطالبات على استمارة

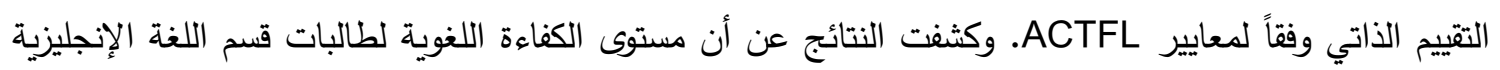
وفقاً لمعايير ACTFL هو متوسط منخفض، وبناءً على نتائج الدراسة تم أوصت الباحثة بعدد من التوصيات وكذلك التهاء

$$
\text { وضعت المقترحات للدراسات المستقبلية. }
$$

الكلمات المفتاحية: أكتفل، الطالبات المعلمات، الأداء التدريسي، الكفاءة، طلاب اللغة الإنجليزية 
International Journal of Applied Linguistics \& English Literature, 3(1), 143-151.

Armstrong, P. (2015). Teacher Characteristics and Student Performance: An Analysis Using Hierarchical Linear Modelling. South African Journal of Childhood Education, 5(2), 123-145.

Banks, T. (2014). Teacher Education Reform in Urban Educator Preparation Programs. Journal of Education and Learning, 4(1), 60-71.

Bird, D. (2017). Relationship between Teacher Effectiveness and Student Achievement: An Investigation of Teacher Quality. Unpublished Ph.D. dissertation. Faculty of Education, Ball State University, Indiana.

Cing, N. (2014). Teachers' English Proficiency and Teaching Efficacy as Correlates of Effective Teaching. Unpublished Master's thesis. Faculty of Education, Adventist University of the Philippines.

Cox, T. \& Malone, M. (2018). A Validity Argument to Support the ACTFL Assessment of Performance toward Proficiency in Languages (AAPPL). Foreign Language Annuals, 51(3), 548574.

Hoge, D. (2016). The Relationship between Teachers' Instructional Practices, Professional Development, and Student Achievement. Unpublished Ph.D. dissertation. Faculty of Education, University of Nebraska.
Kamimura, M. (2018). Intercultural Communicative Competence of NoviceLevel Japanese Learners. Unpublished Master's thesis. Faculty of Education, California State University.

Kissling, E. \& O'Donnell, M. (2015). Increasing Language Awareness and Self-efficacy of FL Students Using Selfassessment and the ACTFL Proficiency Guidelines. Language Awareness, 24(4), 283-302.

Moeller, A. \& Yu, F. (2015). NCSSFL-ACTFL Can-Do Statements: An Effective Tool for Improving Language Learning within and outside the Classroom, Retrieved January 3, 2020, from https://files.eric.ed.gov/fulltext/EJ10802 53.pdf

Seebruck, R. (2015). Teacher Quality and Student Achievement: A Multilevel Analysis of Teacher Credentialization and Student Test Scores in California High Schools. McGill Sociological Review, 5(1), 1-18.

Sirait, S. (2016). Does Teacher Quality Affect Student Achievement? An Empirical Study in Indonesia. Journal of Education and Practice, 7(27), 34-41.

VonBurg, K. (2019). Student Perceptions on Being Assessed by the ACTFL OPI before and after Studying Abroad. Honors thesis. Modern Languages, University of Mississippi. 


\section{Recommendation:}

Based on the study findings, some relevant recommendations are suggested. These include several important issues as follows:

- The English Department should not depend on student's score in the General Secondary School Certificate Exams (SSC) as the only criteria for admission in the English Department. SSC should be looked upon just as a requirement for taking the entry test at the university. All candidates admitted to the Department of English Language at Najran University should take an English language skills test and, based upon the results, candidates are to be admitted or rejected. Moreover, admitted students should first enrol in an intensive bridge program for one or two semesters according to their grades in the language skills test. Courses in the intensive program should concentrate on developing language skills, including listening, comprehension, reading, writing, speaking, grammar, and vocabulary. Upon successful completion of this program, students are matriculated in the actual academic mainstream English program.

- For the English department course designers, there seems to be a need to revise the course outline of major English courses putting more emphasis on the development of the four basic language skills.

- The in-service training program should focus on developing EFL teachers' skills in both the academic field and the teaching performance.

\section{Suggestion for further studies:}

Further research is needed to investigate Saudi EFL teachers and student teachers' current level of proficiency in the language.
The present study deals with the pre-service teacher only. Similar studies may be conducted on in-service teachers to assess their teaching competence as related to their academic qualifications and professional experience.

\section{ACKNOWLEDGMENTS}

The author would like to express her gratitude to the Ministry of Education (Saudi Arabia) and the Deanship of Scientific Research at Najran University (Kingdom of Saudi Arabia) for their financial and technical support under code number (NU/ SHED/17/179).

\section{References:}

ACTFL (American Council on the Teaching of Foreign Languages). (2012). ACTFL Proficiency Guidelines 2012. Retrieved May 5, 2019, from https://www.actfl.org/

Al-Aqad, E. (2017). Evaluating Secondary Stage English for Palestine in the Light of the American Council for the Teaching of Foreign Languages (ACTFL) Standards. Unpublished Master's thesis. Faculty of Education, The Islamic University, Gaza.

Alhajori, S. \& Aljarah, M. (2016). The Guidelines of the American Council on the Teaching of Foreign Languages: An Analytical Descriptive Study of Levels, Skills, and Competencies. Al-athar Journal, 25(1), 83-105.

Alrwele, N. (2018). Assessment of English Language Student Teachers' Perceptions of their Competency in Light of Teacher Professional Standards (ELTPSs) in the Kingdom of Saudi Arabia. The Arab Journal for Quality Assurance in Higher Education, 11(35), 187-218.

Al-Seghayer, K. (2014). The Actuality, Inefficiency, and Needs of EFL TeacherPreparation Programs in Saudi Arabia. 
Table (9): Courses in the English Language Program

\begin{tabular}{|c|c|c|c|c|c|c|c|}
\hline \multicolumn{8}{|c|}{ Categories and count of courses } \\
\hline Levels & $\begin{array}{c}\text { Language } \\
\text { Skills }\end{array}$ & $\begin{array}{c}\text { Cultural } \\
\text { Preparation }\end{array}$ & Literature & Education & $\begin{array}{l}\text { Research } \\
\text { Methods }\end{array}$ & Other & Total \\
\hline First & 4 & 2 & & 1 & & & 7 \\
\hline Second & 4 & 2 & & 1 & & & 7 \\
\hline Third & 5 & 1 & & & & & 6 \\
\hline Fourth & 5 & 1 & & & & & 6 \\
\hline Fifth & 3 & & 1 & 2 & & & 6 \\
\hline Sixth & 3 & & 4 & & & & 7 \\
\hline Seventh & 1 & & & 3 & 1 & 1 & 6 \\
\hline Eighth & & & & 1 & & & 1 \\
\hline Total & 25 & 6 & 5 & 8 & 1 & 1 & 46 \\
\hline Percent & $54 \%$ & $13 \%$ & $11 \%$ & $17.4 \%$ & $2.2 \%$ & $2.2 \%$ & 100 \\
\hline
\end{tabular}

In accordance with the findings shown above, related studies have clearly revealed the fact that some current English teachers in Saudi Arabia feel that they have not been adequately prepared in college to teach in terms of content knowledge and teaching skills as well (AlSeghayer, 2014). They, moreover, believe that they need to learn more effective practices and specific skills to do so (Banks, 2014).

The findings underlined in this research reveal that there is a statistically significant relationship between the student teachers' level of language proficiency and ACTFL Guidelines as well as between the student teachers' level of ACTFL Guidelines and their (GPA.L). This result, therefore, demonstrates the validity of the self-assessment checklist in predicting the actual proficiency level of the EFL student teachers' language skills. This relationship between student teachers' overall language ability and their prediction of the four language skills may be considered as a fair predictor of student achievement because our university system does not evaluate students before they enter the English Department. Therefore, the ACTFL checklist seems to be a valid predictor of student achievement. These findings were consistent with the study done by Cox and Malone (2018), which present relevant evidence by summarizing an analysis of a 2014 test data from examinations administered in three languages (Chinese, French, and Spanish) to more than 10,000 students in grades 5 to 12 . The specific stages the researchers evaluated included the following: (1) the design of the instrument, (2) the effectiveness of the rating scale, (3) the reliability of the instrument, and (4) the extent to which ACTFL proficiency Guidelines were generalizable across languages. This study shows that there is validity evidence that the Assessment of Performance toward Proficiency can be used to measure the performance of upper elementary, middle, and high school students as they develop increasingly sophisticated language proficiency.

With regard to the relationship between the student teachers' level of ACTFL Guidelines and their teaching performance, the result seems to be logical since a language teacher's most important characteristic is her mastery of all the language skills she teaches. If a language teacher is weak in language skills, she may not perform well even if she has been highly prepared professionally. Findings in this aspect are in line with those of Cing (2014), which report that there is a significant correlation between teachers' English proficiency and teaching effectiveness. Moreover, teachers teaching the English language in the classrooms must be proficient in the English language. 


\begin{tabular}{|c|c|c|c|c|c|c|c|c|c|}
\hline & $\begin{array}{l}\text { Management } \\
\text { of Learning }\end{array}$ & $.893 * *$ & 1 & & & & & & \\
\hline & $\begin{array}{l}\text { Language } \\
\text { Proficiency }\end{array}$ & $.571 * *$ & $.672 * *$ & 1 & & & & & \\
\hline & $\begin{array}{l}\text { Assessment } \\
\text { \& Evaluation }\end{array}$ & $.939 * *$ & $.982 * *$ & $.668^{* *}$ & 1 & & & & \\
\hline \multirow{4}{*}{$\begin{array}{c}\text { Self- } \\
\text { Assessment } \\
\text { (ACTFL) }\end{array}$} & Listening & $.535 * *$ & $.547 * *$ & $.461 * *$ & $.539 * *$ & 1 & & & \\
\hline & Speaking & $.805 * *$ & $.753 * *$ & $.563 * *$ & $.781 * *$ & $.641 * *$ & 1 & & \\
\hline & Reading & $.805 * *$ & $.753 * *$ & $.563 * *$ & $.781 * *$ & $.641 * *$ & $1.000 * *$ & 1 & \\
\hline & Writing & $.747 * *$ & $.696^{* *}$ & $.603 * *$ & $.721 * *$ & $.585 * *$ & $.951 * *$ & $.951 * *$ & 1 \\
\hline
\end{tabular}

Table (7) indicates a statistically significant correlation at $(\alpha \leq 0.05)$ between the Student Teachers' Level of ACTFL Guidelines and their Teaching Performance.

Results Related to the Answer of SubQuestion (4):

- Is there any statistically significant relationship between EFL student teachers' overall academic performances and their teaching performance?
In order to determine any possible relationship between EFL student teachers' (GPA) and their teaching performance, Pearson correlation analysis was carried out. Table (8) displays the results of the correlation analysis.

\begin{tabular}{|c|c|c|c|c|c|}
\hline & $\begin{array}{l}\text { Academic } \\
\text { Average }\end{array}$ & $\begin{array}{c}\text { Planning } \\
\text { of } \\
\text { Learning }\end{array}$ & $\begin{array}{l}\text { Management of } \\
\text { Learning }\end{array}$ & $\begin{array}{l}\text { Language } \\
\text { Proficiency }\end{array}$ & $\begin{array}{l}\text { Assessment } \\
\text { and } \\
\text { Evaluation }\end{array}$ \\
\hline Academic Average & 1 & & & & \\
\hline Planning of Learning & $.927 * *$ & 1 & & & \\
\hline Management of Learning & $.797 * *$ & $.893 * *$ & 1 & & \\
\hline Language Proficiency & $.539 * *$ & $.571 * *$ & $.672 * *$ & 1 & \\
\hline Assessment and Evaluation & $.854 * *$ & $.939 * *$ & $.982 * *$ & $.668 * *$ & 1 \\
\hline
\end{tabular}

Table (8) above demonstrates findings related to the correlation between student teachers' teaching practice performance and their (GPA). The findings indicate that the EFL teachers' teaching performance is highly correlated with their (GPA).

This result seems to be logical since a language teacher's most important characteristic is her mastery of all the language skills she teaches.

\section{Discussion:}

To sum up, the results indicate that the participants perceived themselves as (intermediate low) level in language proficiency. Such findings could be attributed to the nature of their preparation program, which gives great emphasis to cultural and educational aspects in teaching. Moreover, these courses were taught through the Arabic language, except for 'Learning and Teaching Strategies' courses and 'Language acquisition', which were taught through English by the English Department. Table (9) offers a brief description of the categories and count of the program courses. 


\begin{tabular}{|c|c|c|c|c|c|c|c|c|c|}
\hline \multirow{4}{*}{$\begin{array}{l}\text { Prof } \\
\text { icie } \\
\text { ncy } \\
\text { Test }\end{array}$} & $\begin{array}{l}\text { Lis } \\
\text { teni } \\
\text { ng }\end{array}$ & 1 & & & & & & & \\
\hline & $\begin{array}{l}\text { Spe } \\
\text { aki } \\
\text { ng }\end{array}$ & $\begin{array}{c}.55 \\
0^{* *}\end{array}$ & 1 & & & & & & \\
\hline & $\begin{array}{l}\mathrm{Wr} \\
\text { itin } \\
\mathrm{g}\end{array}$ & $\begin{array}{c}.63 \\
7 * *\end{array}$ & $\begin{array}{r}.72 \\
3^{* *}\end{array}$ & 1 & & & & & \\
\hline & $\begin{array}{l}\text { Re } \\
\text { adi } \\
\text { ng }\end{array}$ & $\begin{array}{c}.57 \\
5 * *\end{array}$ & $\begin{array}{c}.62 \\
0^{* *}\end{array}$ & $\begin{array}{c}.73 \\
9 * \\
*\end{array}$ & 1 & & & & \\
\hline \multirow{4}{*}{$\begin{array}{c}\text { Self } \\
- \\
\text { Ass } \\
\text { ess } \\
\text { men } \\
\text { t }\end{array}$} & $\begin{array}{l}\text { Lis } \\
\text { teni } \\
\text { ng }\end{array}$ & $\begin{array}{l}.64 \\
1 * *\end{array}$ & $\begin{array}{c}.77 \\
8^{* *}\end{array}$ & $\begin{array}{c}.79 \\
8^{*} \\
*\end{array}$ & $\begin{array}{c}.70 \\
5^{*} \\
*\end{array}$ & 1 & & & \\
\hline & $\begin{array}{l}\text { Spe } \\
\text { aki } \\
\text { ng }\end{array}$ & $\begin{array}{l}.64 \\
1 * *\end{array}$ & $\begin{array}{c}1.0 \\
00^{*} \\
*\end{array}$ & $\begin{array}{l}.77 \\
8^{*} \\
*\end{array}$ & $\begin{array}{c}.79 \\
8 * \\
*\end{array}$ & $\begin{array}{l}.70 \\
5 * *\end{array}$ & 1 & & \\
\hline & $\begin{array}{l}\text { Re } \\
\text { adi } \\
\text { ng }\end{array}$ & $\begin{array}{c}.58 \\
5 * *\end{array}$ & $\begin{array}{l}.95 \\
1 * *\end{array}$ & $\begin{array}{c}.95 \\
1 * \\
*\end{array}$ & $\begin{array}{c}.77 \\
1^{*} \\
*\end{array}$ & $\begin{array}{l}.73 \\
6^{* *}\end{array}$ & $\begin{array}{l}.71 \\
6^{* *}\end{array}$ & 1 & \\
\hline & $\begin{array}{l}\mathrm{Wr} \\
\text { itin } \\
\mathrm{g}\end{array}$ & $\begin{array}{c}.58 \\
5^{* *}\end{array}$ & $\begin{array}{c}1.0 \\
00^{*} \\
*\end{array}$ & $\begin{array}{l}.95 \\
1 * \\
*\end{array}$ & $\begin{array}{l}.95 \\
1 * \\
*\end{array}$ & $\begin{array}{l}.77 \\
1 * *\end{array}$ & $\begin{array}{l}.73 \\
6^{* *}\end{array}$ & $\begin{array}{c}.71 \\
6^{*} \\
*\end{array}$ & 1 \\
\hline
\end{tabular}

* Correlation is significant at the 0.05

** Correlation is significant at the 0.01
Table (5) reveals a significant correlation between the overall language proficiency skills of the EFL student teachers as measured by the self-assessment checklist and the proficiency tests at $(\alpha \leq 0.05)$. This result, therefore, demonstrates the validity of the self-assessment checklist in predicting the actual proficiency level of the EFL student teachers' language skills.

\section{Results Related to the Answer of Sub- Question (2):}

- Is there any statistically significant relationship between the student teachers' level of ACTFL Guidelines and their academic performance of language courses (GPA.L)?

In order to determine any possible relationship between the student teachers' level of ACTFL Guidelines and their (GPA.L), Pearson correlation analysis was carried out. Table (6) displays the results of the correlation analysis.

Table (6): Correlation Coefficient between the Student Teachers' Level of ACTFL Guidelines and their Academic Performance (GPA.L)

\begin{tabular}{|c|l|c|c|c|c|c|}
\cline { 3 - 7 } \multicolumn{2}{c|}{} & \multirow{2}{*}{$\begin{array}{c}\text { Academic } \\
\text { Average }\end{array}$} & \multicolumn{4}{c|}{ Self-assessment (ACTFL) } \\
\cline { 3 - 7 } \multicolumn{2}{c|}{ Academic Average } & 1 & Listening & Speaking & Reading & Writing \\
\hline \multirow{2}{*}{$\begin{array}{c}\text { Self- } \\
\text { assessment } \\
(\text { ACTFL })\end{array}$} & Listening & $.829^{* *}$ & 1 & & & \\
\cline { 2 - 7 } & Speaking & $.829^{* *}$ & $1.000^{* *}$ & 1 & & \\
\cline { 2 - 7 } & Reading & $.753^{* *}$ & $.951^{* *}$ & .951 & 1 & \\
\cline { 2 - 7 } & Writing & $.753^{* *}$ & $.951^{* *}$ & $.95^{* *} 1$ & $1.000^{* *}$ & 1 \\
\hline
\end{tabular}

Table (6) indicates a statistically significant correlation at $(\alpha \leq 0.05)$ between the Student Teachers' Level of ACTFL Guidelines and their (GPA.L).

Results Related to the Answer of SubQuestion (3):

- Is there any statistically significant relationship between the student teachers' level

Table (7): Correlation Coefficient between the Student Teachers' Level of ACTFL Guidelines and their Teaching Performance

\begin{tabular}{|c|l|c|c|c|c|c|c|c|}
\multicolumn{2}{c|}{} & \multicolumn{9}{|c|}{ Observation Checklist } & \multicolumn{4}{|c|}{ Self-Assessment (ACTFL) } \\
\cline { 2 - 8 } & $\begin{array}{c}\text { Planning of } \\
\text { Learning }\end{array}$ & $\begin{array}{c}\text { Management } \\
\text { of Learning }\end{array}$ & $\begin{array}{c}\text { Language } \\
\text { Proficiency }\end{array}$ & $\begin{array}{c}\text { Assessment } \\
\text { and } \\
\text { Evaluation }\end{array}$ & Listening & Speaking & Writing & Reading \\
Checklist & $\begin{array}{l}\text { Planning of } \\
\text { Learning }\end{array}$ & 1 & & & & & & \\
\hline
\end{tabular}

of ACTFL Guidelines and their teaching performance?

In order to determine any possible relationship between the student teachers' level of ACTFL Guidelines and their teaching performance, Pearson correlation analysis was carried out. Table (7) displays the results of the correlational analysis. 
To what extent do English language student teachers at Najran University evaluate their level of proficiency according to the American Council on the Teaching of Foreign Languages (ACTFL)?
Table (3) displays outcomes related to English language student teachers' evaluation of their level of proficiency according to ACTFL.

Table (3): Participants' Level of Proficiency According to American Council on the Teaching of Foreign Languages (ACTFL)

\begin{tabular}{|l|l|c|c|c|}
\hline \multicolumn{1}{|c|}{ Skill } & $\mathbf{N}$ & Means & Std. Deviation & Proficiency Level \\
\hline Listening & 62 & 3.6290 & 1.24445 & Intermediate Low \\
\hline Speaking & 62 & 3.6290 & 1.22012 & Intermediate Low \\
\hline Reading & 62 & 3.8065 & 1.22593 & Intermediate Low \\
\hline Writing & 62 & 3.8065 & 1.22593 & Intermediate Low \\
\hline Total & 62 & 3.7177 & 1.24445 & Intermediate Low \\
\hline
\end{tabular}

Table (3) shows that the total mean of English language student teachers' evaluation of their level of proficiency is (3.7177). Referring to the score limits of proficiency levels which are designed in the data analysis section, the mean score (3.7177) falls in the class (Intermediate Low). Based on the rating of their proficiency according to the four language skills of ACTFL, 'Reading and Writing' had the highest score with a mean of (3.8065), which is interpreted as

Table (4): Levels of ACTFL Proficiency Guidelines and their Numerical Scores

\begin{tabular}{|l|c|}
\hline \multicolumn{1}{|c|}{ Proficiency Rating (Ordinal Scale) } & Numerical Rating (Interval Scale) \\
\hline Novice Low & 1 \\
\hline Novice Mid & 2 \\
\hline Novice High & 3 \\
\hline Intermediate Low & 4 \\
\hline Intermediate Mid & 5 \\
\hline Intermediate High & 6 \\
\hline Advanced Low & 7 \\
\hline Advanced Mid & 8 \\
\hline Advanced High & 9 \\
\hline Superior & 10 \\
\hline Distinguished & 11 \\
\hline
\end{tabular}

Results Related to the Answer of SubQuestion (1):

- Is there any statistically significant relationship between the student teachers' level of language proficiency and ACTFL Guidelines?

Table (5): Pearson Correlation between Self-Assessment Checklist of ACTFL Guidelines and Proficiency Test

\begin{tabular}{|c|c|}
\hline Proficiency Test & Self-Assessment \\
\hline
\end{tabular} (ACTFL)
Intermediate Low, followed by 'Listening and Speaking' with a mean of (3.6290), which is also interpreted as Intermediate Low. To sum up, the participants evaluated themselves as Intermediate Low in language proficiency.

For the purpose of data analysis, Proficiency ratings (ordinal scale) were converted into numerical scores (interval scale), as follows:
In order to determine any possible relationship between the Self-Assessment Checklist of ACTFL Guidelines and Proficiency Test, Pearson correlation analysis was carried out. Table (5) displays the results of the correlation analysis. 
with them individually. The participants were given an opportunity to plan their response within 15 minutes and 45 seconds to speak.

The researcher used the analytic scale to measure the student's performance on various aspects of communication, such as the use of grammar, pronunciation, stress and intonation, accuracy, fluency, and knowledge about contents and ideas. The rating system involved varying degrees of speaking proficiency by using a 1 to 5 rating scale to indicate the strengths and weaknesses of the subject's speaking proficiency.

Reading Test: As stated earlier the researcher used the TOEFL mini-test of the reading skill in order to evaluate the subjects' reading comprehension. This mini-test consisted of an article titled "The Beginning of Organizational Psychology". The reading passage was followed by ten multiple-choice questions, which assessed different areas of comprehension such as 'literal' level of comprehension; 'inferential' level of comprehension; and 'evaluative' level of comprehension. After the second lecture of "Learning and Teaching Strategies", the researcher asked five EFL student teachers to sit for a trial test. The subjects were informed that the average time needed to answer the reading test was 35 minutes.

Table (2): The Value of Reliability Coefficient of the Proficiency Test Using Cronbach's Alpha Method

\begin{tabular}{|l|c|}
\hline \multicolumn{1}{|c|}{ Test Sections } & Cronbach's Alpha \\
\hline Listening & $0.406^{*}$ \\
\hline Speaking & $0.965^{* *}$ \\
\hline Reading & $0.997^{* *}$ \\
\hline Writing & $0.987^{* *}$ \\
\hline
\end{tabular}

Results in Table (2) indicate that the values of reliability coefficients for each domain were high, except listening, which was moderate. These results reflect the reliability of the observation tool.

\section{Statistical Analysis:}

Writing Test: The writing proficiency test consisted of a topic familiar to the student teachers. They were asked to write an essay in response to a question that asks them to state, explain, and support their opinion on an issue. Their essay was supposed to have a minimum of 300 words and they had 30 minutes to plan and complete their essay. Their essay was judged based on the quality of their writing. This includes the development of their ideas, the organization of their essay, and the quality and accuracy of the language they used to express their ideas. The researcher informed the subjects that the test given to them was for the research purpose only and the main aim of the test was to collect data pertaining to the completion of scientific research.

Validity of the Proficiency Test: The test was introduced to a jury of specialists in the English language and methodology in Saudi universities. The items of the test were modified according to their recommendations.

\section{Reliability of the Proficiency Test:} Cronbach's Alpha method of measuring reliability was then estimated on a sample of 25 EFL teachers concerning domains. The results are shown in the following table:

In this study, the researcher uses SPSS package (version 22). To test and analyse the data, the researcher uses the following statistics: Percentages, Means, Standard Deviations, and Pearson's r (Pearson Correlation Coefficient).

\section{Results:}

The results of the major question are displayed first, followed by the results associated with the sub-questions. Lastly, the findings are discussed and interpreted.

\section{Results Related to the Major Question:}




\section{2) Self-Assessment Checklist}

A self-assessment checklist was developed by the researcher based on ACTFL Proficiency Guidelines (2012). This checklist has four main sections in which each section determines the language proficiency of specific language skills: listening, speaking, reading, and writing. In these guidelines, there are five main levels for each skill. i.e. novice, intermediate, advanced, superior and distinguished. A further subdivision has been made within some levels as follows: (novice low, novice mid, novice high), (intermediate low, intermediate mid, and intermediate high), (advanced low, advanced mid, advanced high), (superior) and (distinguished). This selfassessment checklist was administrated during the sixth and seventh weeks of the second semester of the academic year 1440-2019. The researcher met with all the $62 \mathrm{EFL}$ student teachers who were studying 'Teaching and Learning Strategies' upon the end of one of their lectures. This instrument was administrated individually. So, 62 copies of the self-assessment checklist were distributed to the participants, each copy with a cover page containing instructions and clearly stating that the self-assessment checklists were meant for the research purpose only and the main aim of this instrument was to collect data pertaining to the completion of scientific research. The participants were also assured that their responses would not have any effect on their grades in any way, and would not be communicated to anybody. With this, they were relaxed and willingly participated in the process. The participants were asked to read each section 'reading, writing, listening, and speaking' carefully within ten minutes. They were told to put a tick $(\sqrt{ })$ at the item that describes best their skills and abilities. Most of the participants completed doing the selfassessment checklist within 30 minutes. The researcher received all of the 62 copies of the instruments.
Validity of the self-assessment checklist: In order to test the suitability of the selfassessment checklist, it was given to a group of specialists in TEFL methodology at Najran University and some other Saudi universities. They were requested to check the suitability and clarity of the instrument's statements. They were further requested to judge the logical sequences of the Self-Assessment Checklist's statements according to ACTFL Proficiency Guidelines levels. See Appendix B.

Reliability of the Self-Assessment Checklist: After applying the self-assessment checklist to the pilot sample consisting of 25 students, the reliability was calculated by Cronbach's Alpha Coefficient, which was (0.992). This value is accepted for the purposes of this study.

\section{3) Proficiency Tests:}

The main purpose of this study is to explore the EFL student teachers' proficiency 'academic performance' vis-à-vis their teaching performance in the light of the ACTFL Proficiency Guidelines (2012). In this part, the researcher used sample TOEFL mini-tests of the four language skills to determine the real level of the subjects' language proficiency. The purpose of these tests was to evaluate the English language proficiency skills - i.e. reading, listening, speaking, and writing - of people whose native language is not English. The TOEFL mini-tests (2019-2020) were taken from a TOEFL practice test website (TST Prep https://tstprep.com/).

Listening Test: The listening test consisted of a conversation between a student and a professor titled 'study abroad in Guatemala'. The subjects were given 10 minutes to listen to the conversation and then respond to the five multiple-choice questions.

Speaking Test: Regarding the speaking test, the examiner tested the students one by one, by asking a question about a familiar topic 
doing their teaching practicum in partial fulfilment of the requirements for $\mathrm{BA}$ in education, at the Faculty of Science and ArtsSharurah, Najran University, during the first semester of the academic year 1441 Hijri (2020). The total number of participating EFL student teachers was (62).

\section{Research instruments:}

To fulfil the objectives of the study, the three following instruments were used:

1. An observation checklist designed by the researcher to evaluate EFL student teachers' performance and determine the extent to which their performance matches the standards.

2. Self-assessment checklist based on ACTFL Guidelines to determine EFL student teachers' language proficiency for each skill - i.e. listening, speaking, reading, and writing.

3. Proficiency Tests to evaluate the English language proficiency skills, consisting of four sections: listening, speaking, reading, and writing.

A brief description of study instruments is presented below.

\section{1) Observation Checklist}

Good teaching requires four types of knowledge and skills: basic academic skills, thorough content knowledge of each subject to be taught, knowledge of both generic and content-specific pedagogy, and hands-on teaching skills. Thus, the observation checklist consisted of four main domains: planning of learning, management of learning, language proficiency, and assessment and evaluation.

Table (1): The Value of Reliability Coefficient of the Observation Checklist Using Cronbach's Alpha Method

\begin{tabular}{|l|c|c|}
\hline \multicolumn{1}{|c|}{ Fields } & Cronbach's Alpha & Items No. \\
\hline Planning of Learning & .978 & 7 \\
\hline Management of Learning & .996 & 6 \\
\hline Language Proficiency & .957 & 7 \\
\hline Assessment and Evaluation & .972 & 4 \\
\hline Total & .985 & 24 \\
\hline
\end{tabular}

The assessment scale adopted for the observation checklist was a five-point scale: 5 meaning 'always', 4 meaning 'often', 3 meaning 'sometimes', 2 meaning 'rarely', and 1 meaning 'never'.

The observation checklist was applied by two respective student teachers' supervisors (raters) to each student-teacher. The supervisors met with the student teachers before the beginning of the lesson and told them that this observation was being made for the research purpose only and the main aim of this checklist was to collect data pertaining to the completion of scientific research. They were also assured that this checklist would not have any effect on their grades in the teaching practice anyway, and would not be communicated to anybody.

Validity of the observation checklist: In order to determine its validity, the observation checklist was given to five specialists in English teaching methodology at Najran University (Sharurah campus) to see if the instrument would serve the purpose of the study well. They were requested to make any modifications if and where necessary. In the light of the jury's suggestions, the researcher made the necessary changes and prepared the final draft of the observation checklist. See appendix A.

Reliability of the Observation Checklist: In order to check the reliability of the observation checklist, Cronbach's Alpha method was estimated on a sample of 20 EFL teachers concerning domains and the total. The results are shown in the following table:

Results in Table (1) indicate that the values of reliability coefficients for the domains and the total score were between 0.957-0.996, which are considered high values, and confirm the reliability of the observation tool. 
Since World-Readiness Standards for Learning Languages (ACTFL, 2017) articulate the development of linguistic and intercultural communicative competence as important outcomes of world language education in secondary and post-secondary schools, the study of Kamimura (2018) attempted to discover if the Observe State Explore Evaluate (OSEE) Tool (Deardorff, 2009) increased the intercultural communicative competence among novice level high school Japanese language learners in a quantitative nonequivalent group, pretest-posttest quasiexperimental design. Can-Do Statements for Intercultural Communication (ACTFL, 2017) were used as the pretest and posttest measurements. Study participants were 44 high school students in their second semester of the second year Japanese class during the weather report unit. Twenty-one participants in the treatment group received the OSEE Tool intervention. Analyses of the independent and paired t-tests showed that the increase of mean scores between pretest and posttest was bigger and the standard deviation figures were smaller in the treatment group than the control group.

Al-Aqad (2017) investigated whether newly implemented English syllabus for Palestine students matched the requirements of the modern and global trends. The researcher prepared a content analysis card to collect data. The data involved making a survey for the two pupil books of the syllabus in order to analyse it and ensure that it matched the American Council for the Teaching of Foreign Languages (ACTFL) Standards. After applying the analysis card, the results showed a variation in the distribution of the five standards in English for Palestine. Some standards scored high while others scored low. The researcher recommended creating a balance in distributing the five main standards, in addition to its nine sub-standards. It is important to note that balance does not mean equality, but rather the distribution of the standards according to their importance. In addition, the study urged that the two Palestinian English books of grade 11 \& 12 be modified and developed to cope and agree with modern and latest global standards of teaching English as a foreign language.

VonBurg (2019) investigated the perceptions of students of the American Council on the Teaching of Foreign Language (ACTFL) before and after studying abroad. But his work was limited to oral proficiency. The participants were 96 students who were International Studies majors at the University of Mississippi. Students in this program take a foreign language course every semester, study abroad for at least one semester, and take ACTFL before graduation. The participants completed an online survey that assessed their perceptions of being assessed by means of ACTFL. The results of the survey revealed that pre-study abroad participants had more positive and optimistic opinions. On the other hand, post-study abroad participants had negative opinions. This research also demonstrated that students knew and understood the development they had made during their study abroad experience, but the students were on the other hand feeling that they were not able to show all of the improvements and gains that they had made through this assessment. Because ACTFL is a high stakes test, these students wanted to put their best foot forward and show their best language skills, but they were unable to do so.

Finally, the review of literature paved the way for the researcher to prepare the instruments of the study in addition to interpreting the results of the study. Moreover, it provided the researcher with insights into the various aspects of ACTFL Guidelines.

\section{Research Methodology:}

The study adopts a descriptive research design in order to determine whether Saudi EFL student teachers' performance at Najran University matches ACTFL Proficiency Guidelines. The subjects of the study consisted of all female EFL student teachers who are 
profound impact on language teaching and learning in the United States. (ACTFL Proficiency Guidelines, 2012)

The upcoming section will review in brief relevant studies conducted in this context, taking chronological order into account.

Moeller and $\mathrm{Yu}$ (2015) explore the theoretical foundation of the NCSSFL-ACTFL Can-Do Statements, developed by the National Council of State Supervisors for Languages (NCSSFL) and the American Council on the Teaching of Foreign Languages (ACTFL); describe why and how to use these progress indicators in language education; and reveal the value and impact on student learning when effectively integrated into the language classroom. These Can-Do statements serve as learning goals to document what learners "can do" with languages and can provide teachers and language programs with learning objectives for curriculum and unit design that are userfriendly, learner-centred, and promote reflection and self-regulation aimed at involving the learner directly in the learning process. An exemplar for classroom implementation shows how the teacher can involve learners in the reflective learning process to become independent, self-regulated language learners.

To examine the relationship between self-assessment informed by ACTFL on learners' language awareness and self-efficacy, Kissling \& O'Donnell (2015) investigated the impact of using self-assessment informed by ACTFL on learners' language awareness and notions of self-efficacy. A one-semester quasiexperimental quantitative study was conducted in Spanish classes with a total of 13 participants in an advanced conversation course at a large, public university in the south-eastern United States. The study revealed that self-assessment of oral performance guided by the Proficiency Guidelines is an effective way to increase FL students' language awareness and self-efficacy.
Research has also demonstrated positive results of the impact of these guidelines and their application on Arabic courses taught to speakers of other languages. According to Alhajori and Aljarah's study (2016), the guidelines introduce the common principles and the basic landmarks for the development of courses and educational programs. Their linguistic levels are accurate and fit the learners' needs and educational levels. The study has recommended to be based upon referential scientific frames that fit the learners and introduce the linguistic skills and proficiencies through strict benchmarks to ensure the success of the educational process, accomplish the needed outcomes and unify the efforts of the educational institutions and authorities concerned with the teaching of Arabic. It has suggested that experts and professionals should cooperate to develop a unified framework for Arabic language courses to serve as a guide for composing programs on par with international frameworks.

For the purposes of a validity argument on the ACTFL Assessment of Performance toward Proficiency in Languages tests, Cox and Malone (2018) present relevant evidence by summarizing an analysis of a 2014 test data from examinations administered in three languages (Chinese, French, and Spanish) to more than 10,000 students in grades 5 to 12 . The specific stages the researchers evaluated included the following: (1) the design of the instrument, (2) the effectiveness of the rating scale, (3) the reliability of the instrument, and (4) the extent to which ACTFL proficiency Guidelines were generalizable across languages. This study shows that there is validity evidence that the Assessment of Performance toward Proficiency can be used to measure the performance of upper elementary, middle, and high school students as they develop increasingly sophisticated language proficiency. 
improve the English language program in preparing its graduates to meet the professional teacher standards requirements.

\section{Limitations of the study:}

The study is limited to the final year (14412020) Saudi female student teachers of the English Department at Najran University in Sharurah Province.

\section{Definition of Terms:}

Academic Performance: In this study, academic performance means:

A) (GPA) Grade point average of overall academic performances. It includes all courses in all the English as well as the other general courses within and outside the classroom situation before the practical training period.

B) (GPA.L) Academic performances of English language courses only.

\section{Teaching Performance: Teaching performance refers to the behaviour of the student-teacher while teaching (such as asking questions, giving instructions, showing support, providing explanations, engaging in the numerous instructional acts that a teacher performs in the classroom). Teaching performance in the present study has been specified according to ACTFL Guidelines.}

Language Proficiency: In this study, language proficiency refers to student-teachers' ability to use English language in domains such as listening, speaking, reading, and writing as well as grammatical knowledge.

ACTFL Proficiency Guidelines (American Council on the Teaching of Foreign Languages): ACTFL Proficiency Guidelines are descriptions of what individuals can do with language in terms of listening, speaking, reading, and writing in real-world situations in a spontaneous and non-rehearsed context. (ACTFL Proficiency Guidelines, 2012)

\section{Literature Review:}

As mentioned above, ACTFL Proficiency Guidelines are descriptions of what individuals can do with language in terms of listening, speaking, reading, and writing in real-world situations in a spontaneous and non-rehearsed context. For each skill, these guidelines identify five major levels of proficiency: Novice, Intermediate, Advanced, Superior, and Distinguished. The major levels Novice, Intermediate, and Advanced are subdivided into Low, Mid, and High sublevels. ACTFL Guidelines levels describe a continuum of proficiency from that of the highly articulate, well-educated language user to a level of little or no functional ability. These guidelines present the levels of proficiency as ranges and describe what an individual can and cannot do with language at each level, regardless of when, where, or how the language was acquired. Together these levels form a hierarchy in which each level includes all lower levels. The guidelines are not based on any particular theory, educational curriculum, or pedagogical method. They neither describe how an individual learns a language nor prescribe how an individual should learn a language, and they should not be used for such objectives. They are a tool for the evaluation of functional language ability. (ACTFL Proficiency Guidelines, 2012)

ACTFL Proficiency Guidelines were first published in 1986 as an adaptation for the academic society of the U.S. Government's Interagency Language Roundtable (ILR) Skill Level Descriptions. The direct application of ACTFL Proficiency Guidelines is for the evaluation of functional language ability. The guidelines are intended to be used for global assessment in workplace and academic settings. Nevertheless, they do have instructional implications. ACTFL Proficiency Guidelines underlie the development of the ACTFL Performance Guidelines for learners from kindergarten to $12^{\text {th }}$ grade (1998) and are used in conjunction with the National Standards for Foreign Language Learning (1996, 1998, 2006) to describe how well learners meet content standards. For the past 25 years, ACTFL Guidelines have had an increasingly 
In Najran University, we are perhaps training EFL teachers without taking into consideration proper criteria developed by our own educational system and TEFL experts. The result, therefore, is that we do not have, by and large, quality teachers trained well enough to achieve the goals of quality education.

In this study, the introduction of ACTFL Standards is critical to student-teachers themselves, feeds student-teachers with information about their performance so they can set and develop their practice and, on the other hand, feeds decision-makers with information about student-teachers' performance so that supervisors can make formal decisions related to assessing the quality of current student-teacher training before any possible restructuring acts. Thus, to assess the performance of EFL teachers, there should be clear and objective criteria.

To sum up, it can be said that education improvement requires improvement of teacher's quality, which requires improvement of teacher's performance through authentic assessment. Thus, the need to design an objective and comprehensive tool to assess EFL student teacher's performance has appeared as an important step to improve education.

\section{Statement of the Problem:}

The current research paper comes as an attempt to assess the extent to which ACTFL professional standards for English language teachers are applied by the English language female student teachers at Najran University.

\section{Questions of the Study:}

To what extent do English language student teachers at Najran University evaluate their level of proficiency according to the American Council on the Teaching of Foreign Languages (ACTFL) Guidelines?

Four sub-questions emerged from the major question, which are as follows:

- Is there any statistically significant relationship between student teachers' level of language proficiency and ACTFL Guidelines?

- Is there any statistically significant relationship between student teachers' level of ACTFL Guidelines and their academic performance of language courses?

- Is there any statistically significant relationship between student teachers' level of ACTFL Guidelines and their teaching performance?

- Is there any statistically significant relationship between EFL student teachers' overall academic performances and their teaching performance?

\section{Study Objectives:}

This study aimed to:

1. investigate the language proficiency of student teachers at Najran University in the light of ACTFL Guidelines and its relationship with their teaching performance.

2. investigate the correlation coefficient between academic performance (GPA) of the student teachers and their teaching performance.

\section{Significance of the Study:}

The review of previous literature indicated that there had been no studies carried out to evaluate teaching competencies of English language female student teachers at Najran University according to ACTFL Proficiency Guidelines. Therefore, this would be the first study in that domain. As such, it is expected that this study would pave the way for more studies in the same direction and serve as a future reference for them. The findings of the study may have valuable insights into the strengths and weaknesses of the existing English language teacher preparation program. Hopefully, the results would provide the university decisionmakers with reliable information to promote evidence-informed decisions that might 


\title{
Assessing the EFL Student Teachers Academic and Teaching Performance at Najran University in the Light of ACTFL Proficiency Guidelines
}

\author{
Alzahrani, Ghaida Ali S. \\ Najran University, Kingdom of Saudi Arabia \\ College of Science and Arts-Sharurah \\ gaalzahrani@nu.edu.sa
}

\begin{abstract}
EFL student teachers' level of language proficiency in the light of ACTFL Guidelines, and the correlation between their academic performance (GPA) and their teaching performance. The descriptive method was used. The subjects of the study consist of EFL student teachers practicing teaching during the academic year $1441 \mathrm{H}(\mathrm{N}=62)$. Data were collected through the following three instruments: A) An observation checklist designed by the researcher to evaluate EFL student teachers' performance to determine the extent to which their performance matches the standard; B) Self-Assessment checklist based on ACTFL Guidelines, which determine EFL student teachers' language proficiency for each skill (listening, speaking, reading, and writing); and C) 3 Proficiency Tests to evaluate the English language proficiency skills (including four sections: listening, speaking, reading, and writing). Findings revealed that the student teachers perceived themselves to be (intermediate low) level in language proficiency according to ACTFL Guidelines. Moreover, there is a statistically significant relationship between ACTFL Guidelines and all variables of the study. Based on the research results, recommendations, and suggestions for future studies were proposed.
\end{abstract}

ACTFL: American Council on the Teaching of Foreign Languages.

Keywords: ACTFL, student teacher, teaching performance, proficiency, EFL student.

\section{Introduction}

Teachers are seen as one of the most powerful agents affecting students' learning and their educational success. A long line of research and empirical evidence of student achievement validated the relationship between high-quality teaching and students' high performance (Armstrong, 2015; Seebruck, 2015; Hoge, 2016; Sirait, 2016; Bird, 2017).

Taking this relationship into account, many countries are striving for providing quality teacher education and building up powerful models for educating their future teachers. Internationally, policymakers and authorities worked to professionalize teaching through establishing standards for accreditation "similar to medicine and law" (Alrwele, 2018). Thus, teacher preparation programs and institutions are revised according to accreditation standards and benchmarks.

The process of preparing EFL teachers in Saudi Arabia consists of two main parts; they are the educational part and the language skills part that allow teachers to convey their message and achieve their teaching objectives. In this study, the educational part refers to pedagogy and teaching methodology, while the language skills part refers to teachers' level of proficiency in English. 